\title{
Spectral Property Observations in Lakes Surrounding a Chilean Volcano
}

\author{
Patricio De los Ríos Escalante ${ }^{1,2 *}$, Manuel Castro ${ }^{3}$, \\ Carlos Esse $^{1,2}$, Patricio Acevedo ${ }^{3}$
}

${ }^{1}$ Laboratorio de Ecología Aplicada y Biodiversidad, Escuela de Ciencias Ambientales, Facultad de Recursos Naturales, Universidad Católica de Temuco, Casilla15-D, Temuco, Chile

${ }^{2}$ Núcleo de Estudios Ambientales, UCTemuco

${ }^{3}$ Laboratorio de Teledetección Satelital, Departamento de Ciencias Físicas, Facultad de Ingeniería y Ciencias,

Universidad de La Frontera, Casilla 54-D, Temuco

Received: 29 April 2016

Accepted: 20 June 2016

\begin{abstract}
Northern Chilean Patagonia has numerous pristine lakes associated with Nothofagus and Araucaria araucana forests. The present study consists of a study of optical properties in visible, close, and medium infrared wavelengths in mountain lakes surrounding Llaima Volcano - lakes that have associated Nothofagus and Araucaria araucana native forests with volcanic origins. The results revealed high reflectance values in Arcoiris Lagoon that has volcanic stones in its bottom, whereas the other lakes and lagoons have low reflectance values. These differences in spite of oligotrophy would be associated with surrounding vegetation and geological characteristics of studied sites.
\end{abstract}

Keywords: remote sensing, satellite images, lakes, oligotrophy

\section{Introduction}

The mountain lakes of the Chilean Araucanian Andes $\left(38-39^{\circ} \mathrm{S}\right)$ are oligotrophic, of glacial or volcanic origin. They are associated with native Nothofagus Blume forest, particularly N. antarctica (G. Forst.) Oerst., N. pumilio (Poepp. et Endl.) Krasser, and $N$. dombeyi (Mirb.) Oerst. At altitudes greater than 1,000 m a.s.l., these species coexist with Araucaria araucana (Molina) K. Koch, between $38-39^{\circ} \mathrm{S}$ [1-3]. Some of these lakes have marked volcanic influence because there are active volcanos, such as Llaima, that can expulse their ashes to the surrounding

*e-mail: prios@uct.cl landscapes, consequently affecting inland water bodies [4-5]. Ash from other distant volcanoes also can affect the study area, such as Cordón Caulle [6]. The aim of the present study is to compare spectral properties data obtained from LANDSAT ETM+ in lakes surrounding Llaima Volcano, specifically Icalma and Galletué lakes, and lagoons located within Conguillio National Park (Conguillio, Verde, Arcoiris, and Captrén). Lakes Galletué and Icalma have similar characteristics in depth and surface, whereas the lagoons in Conguillío National Park are small and shallow. From these lagoons Verde and Arcoiris are the lowest [2], with Verde having volcanic material and Arcoiris having submerged vegetation.

Remote sensing allows us to measure reflectance value in oceans, lakes, and rivers using the measurement of reflected light [7-9]. For wavelengths from infrared the 


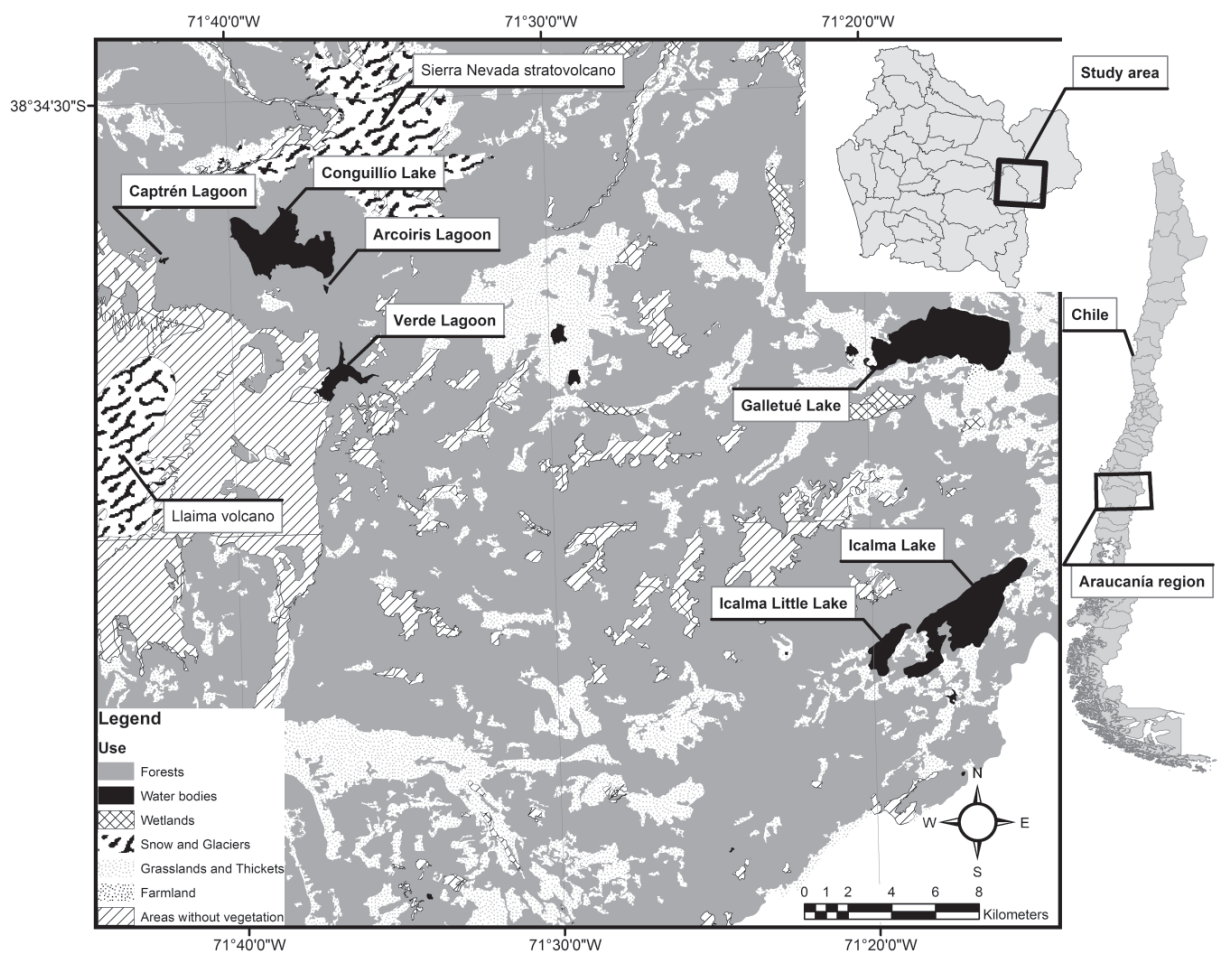

Fig. 1. Study area: North Patagonian Chile (from Native Forest Census - CONAF 2013).

measurements correspond exclusively to water surface, whereas in visible wavelengths these are related to water volume due to more light penetrating into water for these wavelengths for meters of penetration [10-12].

\section{Material and Methods}

\section{Remote Sensing Procedures}

In this step a LANDSAT/ETM+ image is used to obtain dated lakes of Icalma and Galletué and lagoons located within Chile's Conguillio National Park (Fig. 1 and Table 1). This image is dated 12 January 2012 and is provided by the Land Processess Distributed Active Archive Center (LP DAAC) of the U.S. Geological Survey (LPDAAC.usgs.gov). The scene corresponds to path/row

Table 1. Geographical locations and areas of studied lakes.

\begin{tabular}{|c|c|c|}
\hline Lake & Location & $\begin{array}{c}\text { Surface area } \\
\left(\mathrm{km}^{2}\right)\end{array}$ \\
\hline Arcoiris & $38^{\circ} 40^{\prime} \mathrm{S} ; 71^{\circ} 37^{\prime} \mathrm{W}$ & 0.036 \\
\hline Captrén & $38^{\circ} 38^{\prime} \mathrm{S} ; 7^{\circ} 42^{\prime} \mathrm{W}$ & 0.080 \\
\hline Conguillío & $38^{\circ} 40^{\prime} \mathrm{S} ; 7^{\circ} 37^{\prime} \mathrm{W}$ & 8.422 \\
\hline Galletué & $38^{\circ} 40^{\prime} \mathrm{S} ; 7^{\circ} 15^{\prime} \mathrm{W}$ & 12.366 \\
\hline Icalma & $38^{\circ} 40^{\prime} \mathrm{S} ; 7^{\circ} 15^{\prime} \mathrm{W}$ & 9.940 \\
\hline Icalma Chica & $38^{\circ} 40^{\prime} \mathrm{S} ; 7^{\circ} 15^{\prime} \mathrm{W}$ & 2.031 \\
\hline Verde & $38^{\circ} 40^{\prime} \mathrm{S} ; 7^{\circ} 37^{\prime} \mathrm{W}$ & 1.861 \\
\hline
\end{tabular}

233/087, Landsat series. Additionally, two other Landsat/ ETM+ images were used, dated from 6 January 2010 and 9 January 2011.

The spectral and spatial characteristics of the ETM+ sensor are presented in Fig. 2 and Table 2. The bands of visible, near, and mid-infrared were calibrated radiometrically to spectral radiance and then to reflectance with atmospheric correction being applied (Table 3). Data analysis: 2012 reflectance was applied to principal correspondence analysis to obtain the grouping for sampled sites. This statistical analysis was applied using Analyse-it software based on the methodology used for Patagonian lakes [13].

\section{Results and Discussion}

Correlation analysis (Pearson correlation test) to 2012 data revealed direct significant correlations between B1

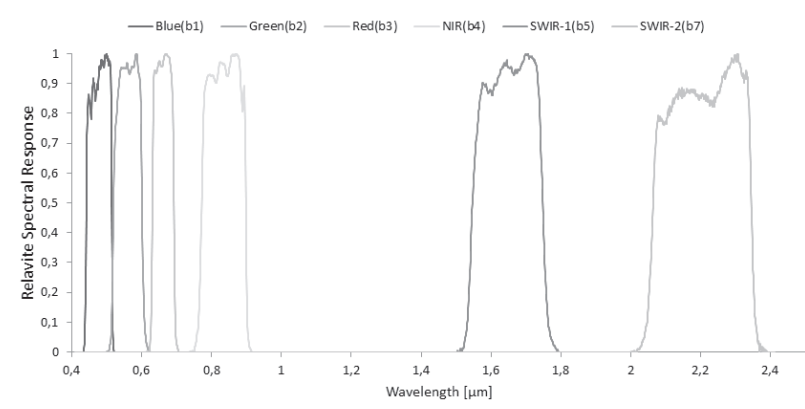

Fig. 2. Relative spectral response, sensor ETM+/Landsat-7. 
Table 2. Technical characteristics of the Landsat7/ETM + sensor.

\begin{tabular}{|c|c|c|c|}
\hline Band & $\begin{array}{c}\text { Spectral range } \\
(\mu \mathrm{m})\end{array}$ & $\begin{array}{c}\text { Wavelength } \\
\text { center }(\mu \mathrm{m})\end{array}$ & GSD $(\mathrm{m})$ \\
\hline PAN & $0.520-0.900$ & 0.720 & 15 \\
\hline 1 & $0.450-0.515$ & 0.479 & 30 \\
\hline 2 & $0.525-0.605$ & 0.561 & 30 \\
\hline 3 & $0.630-0.690$ & 0.661 & 30 \\
\hline 4 & $0.775-0.900$ & 0.835 & 30 \\
\hline 5 & $1.550-1.750$ & 1.650 & 30 \\
\hline 6 & $10.40-12.50$ & 11.450 & 60 \\
\hline 7 & $2.090-2.350$ & 2.208 & 30 \\
\hline
\end{tabular}

with B2 $(\mathrm{R} 2=0.991, \mathrm{p}<0.05), \mathrm{B} 1$ with $\mathrm{B} 3(\mathrm{R} 2=0.932$, $\mathrm{p}<0.05), \mathrm{B} 1$ with $\mathrm{B} 4(\mathrm{R} 2=0.790, \mathrm{p}<0.05), \mathrm{B} 2$ with B3 $(\mathrm{R} 2=0.955, \mathrm{p}<0.05), \mathrm{B} 2$ with $\mathrm{B} 4(\mathrm{R} 2=0.797, \mathrm{p}<0.05)$, $\mathrm{B} 2$ with $\mathrm{B} 5(\mathrm{R} 2=0.755, \mathrm{p}<0.05)$, B3 with $\mathrm{B} 4(\mathrm{R} 2=$ $0.852, \mathrm{p}<0.05), \mathrm{B} 3$ with $\mathrm{B} 5(\mathrm{R} 2=0.814, \mathrm{p}<0.05)$, B3 with B7 $(\mathrm{R} 2=0.794, \mathrm{p}<0.05), \mathrm{B} 4$ with B5 $(\mathrm{R} 2=0.995$, $\mathrm{p}<0.05)$, B4 with B7 (R2 = 0.994, p<0.05), and B5 with $\mathrm{B} 7(\mathrm{R} 2=0.995, \mathrm{p}<0.05)$ (Table 4). PCA revealed that all variables contributed to axis 1 , whereas $\mathrm{B} 1, \mathrm{~B} 2$, and B3 made a positive contribution to axis 2 while B4, B5, and B7 made a negative contribution to axis 2 (Table 5, Fig. 3). This may be due to the different light penetration in water of visible (bands 1,2,3) and infrared wavelengths (bands $4,5,7$ ).

The results of PCA revealed that Verde Lagoon - and partially Conguillio Lagoon and Icalma Lake - have high reflectance for B1, B2, and B3, and low reflectance for B4, B5, and B7, whereas Arcoiris, Icalma Chica, and Captrén lagoons and Galletué Lake (Fig. 1) have low reflectance for B1, B2, and B3 and high reflectance for B4, B5, and B7.

The present study revealed differences in optical properties for studied lakes that could be denoted using remote sensing techniques such as were observed for Patagonian lakes with marked environmental
Table 4. Correlation matrix for variables considered in the present study (values in bold denote significant correlation; $\mathrm{p}<0.05$ ).

\begin{tabular}{|c|c|c|c|c|c|}
\hline & B1 & B2 & B3 & B4 & B5 \\
\hline B6 & 0.749 & 0.751 & $\mathbf{0 . 7 9 4}$ & $\mathbf{0 . 9 9 4}$ & $\mathbf{0 . 9 9 5}$ \\
\hline B5 & 0.750 & $\mathbf{0 . 7 5 5}$ & $\mathbf{0 . 8 1 4}$ & $\mathbf{0 . 9 9 5}$ & \\
\hline B4 & $\mathbf{0 . 7 9 0}$ & $\mathbf{0 . 7 9 7}$ & $\mathbf{0 . 8 5 2}$ & & \\
\hline B3 & $\mathbf{0 . 9 3 2}$ & $\mathbf{0 . 9 5 5}$ & & & \\
\hline B2 & $\mathbf{0 . 9 9 1}$ & & & & \\
\hline
\end{tabular}

heterogeneity such as was observed for lakes Tagua Tagua and General Carrera [13-15].

The environmental heterogeneity for Patagonian lakes has been described in details mainly regarding trophic status and associated basins [16-18], but recently was studied using optical properties associated with ecological implications due to the presence of associated glaciers with consequent changes in water coloration properties, light absorption, and changes in associated trophic webs [19-21], and these results would be associated with optical properties obtained from satellite images [13-15].

All of the studied sites are associated with the volcanic activity of Cordón Caulle and Llaima volcanoes. The Caulle Cordon began in the middle of 2011 with sustained emissions of volcanic ash until early 2012. This ash often covered the area of Conguillio National Park and surrounding zones. Llaima Volcano had weak eruptive activity in early 2012. The ash plumes of both volcanoes affect all surrounding ecosystems for studied sites [20]. Also, the sites included in Conguillio National Park feature the geological characteristic of having many volcanic stones along their bottoms, such as was observed for Verde and Arcoiris lagoons [5]. Also, in Arcoiris Lagoon the high infrared reflectance values are related to the presence of high quantities of submerged vegetation. In this scenario, there is potential correlation between optical, chemical, and trophic status with a consequent response regarding the biological characteristics of the ecosystem [13-15, 22].

Table 3. Reflectance for studied lakes (2010-12).

\begin{tabular}{|c|c|c|c|c|c|c|c|c|c|c|c|c|c|c|c|c|c|c|}
\hline & \multicolumn{3}{|c|}{ B1 (\%) } & \multicolumn{3}{|c|}{ B2 (\%) } & \multicolumn{3}{c|}{ B3 (\%) } & \multicolumn{3}{c|}{ B4 (\%) } & \multicolumn{3}{c|}{ B5 (\%) } & \multicolumn{3}{c|}{ B7 (\%) } \\
\hline Lake & 2010 & 2011 & 2012 & 2010 & 2011 & 2012 & 2010 & 2011 & 2012 & 2010 & 2011 & 2012 & 2010 & 2011 & 2012 & 2010 & 2011 & 2012 \\
\hline Arcoiris & 2.79 & 2.96 & 2.71 & 3.21 & 3.03 & 2.29 & 3.73 & 3.45 & 2.46 & 6.54 & 6.02 & 2.78 & 5.18 & 5.38 & 4.04 & 4.53 & 5.84 & 4.13 \\
\hline Captrén & 3.24 & 2.82 & 1.75 & 3.48 & 2.99 & 1.38 & 3.12 & 2.65 & 1.31 & 4.27 & 3.80 & 0.74 & 3.23 & 2.65 & 1.32 & 2.71 & 2.33 & 0.20 \\
\hline Conguillío & 3.02 & 2.86 & 2.13 & 2.72 & 2.47 & 1.62 & 2.14 & 2.15 & 1.26 & 2.39 & 2.25 & 0.62 & 2.27 & 2.03 & 1.01 & 2.21 & 1.98 & 0.13 \\
\hline Galletué & 2.12 & 2.59 & 1.62 & 1.98 & 2.43 & 1.25 & 2.14 & 2.43 & 0.93 & 2.04 & 2.58 & 0.57 & 2.27 & 2.42 & 0.88 & 2.21 & 2.28 & 0.12 \\
\hline Icalma & 2.12 & 2.63 & 2.01 & 1.98 & 2.41 & 1.64 & 2.14 & 2.43 & 1.18 & 2.04 & 2.60 & 0.63 & 2.27 & 2.46 & 1.06 & 2.21 & 2.28 & 0.21 \\
\hline $\begin{array}{c}\text { Icalma } \\
\text { Chica }\end{array}$ & 1.90 & 2.65 & 1.82 & 1.98 & 2.56 & 1.44 & 1.91 & 2.53 & 1.10 & 1.69 & 2.75 & 0.63 & 1.95 & 2.58 & 1.15 & 2.21 & 2.36 & 0.22 \\
\hline Verde & 3.02 & 3.79 & 2.39 & 2.96 & 3.58 & 2.03 & 2.59 & 2.87 & 2.02 & 2.74 & 2.91 & 0.86 & 2.58 & 2.58 & 1.16 & 2.51 & 2.47 & 0.21 \\
\hline
\end{tabular}


Table 5. PCA contribution percentages of variables for axis 1 and 2 .

\begin{tabular}{|c|c|c|}
\hline & 1 & 2 \\
\hline B1 & 0.401 & 0.458 \\
\hline B2 & 0.403 & 0.460 \\
\hline B3 & 0.411 & 0.303 \\
\hline B4 & 0.418 & -0.342 \\
\hline B5 & 0.409 & -0.423 \\
\hline B6 & 0.407 & -0.437 \\
\hline
\end{tabular}

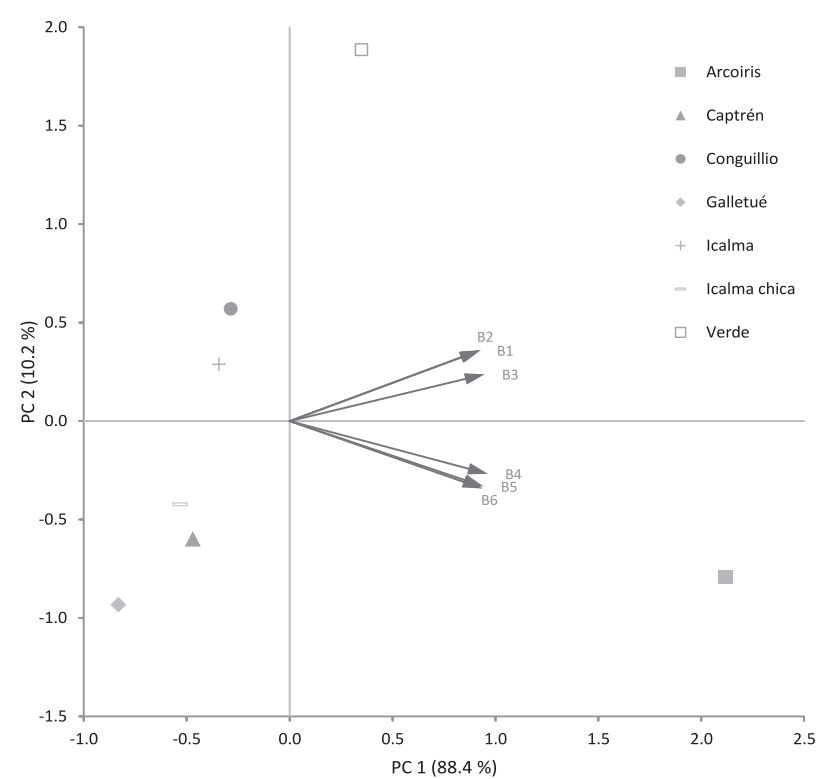

Fig. 3. PCA analysis for variables considered in the present study.

\section{Conclusion}

It is possible to use satellite reflectance data to monitor the chemical and trophic status of lakes and lagoons. This information detects not exclusively differences related to physical features of the lakes, and also recognizes changes of water reflectance generated by ash fall from volcanic plumes. For example, for Arcoiris, Captrén, and Verde in three analyzed data (Table 2), their infrared reflectance values were permanently higher in comparison to other lakes and lagoons, which is due to their low surface and depth. Also, the reflectance value of lakes and lagoons showed a strong decrease in 2012, corresponding to the effect of volcanic ash fall from the Caulle cordon eruption and Llaima volcano eruption.

The results presented indicate a potential correlation between environmental associations due to surrounding basins and that optical properties might possibly be found [23]; however it would be necessary to carry out more intensive studies and obtain more data to be able to confirm or discount the possibility of finding potential correlations and their variation at multiple spatial and temporal scales [24].

\section{Acknowledgements}

The present study was funded by the TIDES TRF1303011 and MECESUP UCT 0804 projects, and we thank M.I for her valuable comments and suggestions.

\section{References}

1. HAUENSTEIN E., BARRIGA K., DE LOS RÍOS-ESCALANTE P. Macrophytes assemblages in mountain lakes of Huerquehue National Park $\left(39^{\circ} \mathrm{S}\right.$, Araucanía Region, Chile). Latin American Journal of Aquatic Research, 39, 593, 2011.

2. DE LOS RÍOS-ESCALANTE P., HAUENSTEIN E., ACEVEDO P., ROMERO-MIERES M., PANDOURSKI I. Regulatory factors in crustacean zooplankton assemblages in mountain lakes of northern Chilean Patagonia (38-41 $\left.{ }^{\circ} \mathrm{S}\right)$ : a comparison with Bulgarian counterparts. Latin American Journal of Aquatic Research, 40, 473, 2012.

3. DE LOS RÍOS P., HAUENSTEIN E., ACEVEDO P., JAQUE X. Littoral crustaceans in mountain lakes of Huerquehue National Park $\left(38^{\circ} \mathrm{S}\right.$, Araucania region, Chile). Crustaceana, 80, 401, 2007.

4. ARANEDA A., CRUCES F., TORRES L., BERTRAND S., FAGEL N., TREUTLER H.C, CHIRINOS L., BARRA R., URRUTIA R. Changes of sub-fossil chironomid assemblages associated with volcanic sediment deposition in and Andean lake ( $\left.38^{\circ} \mathrm{S}\right)$, Chile. Revista Chilena de Historia Natural 80, 141, 2007.

5. GALLARDO M-B., PEREZ C., NUÑEZ-AVILA M., ARMESTO J.J. Desacoplamiento del desarrollo del suelo y la sucesión vegetal a lo largo de una cronosecuencia de 60 mil años en el volcán Llaima, Chile. Revista Chilena de Historia Natural 85, 291, 2012.

6. GOES 8/10 Hot Spot Images. Hawai'I Institute of Geophysics and Planetology. University of Hawai'i. goes.higp.hawaii.edu/goes/index.shtml.

7. OLMANSON L.G., BAUER M.E., BREZONIK P.L. A 20-year Landsat water clarity census of Minnesota's 10,000 lakes. Remote Sensing of Environment, 112, 4086, 2008.

8. DEKKER A.G., VOS R.J., PETERS S.W.M. Comparison of remote sensing data, model results and in situ data for total suspended matter (TSM) in the southern Frisian lakes. Science of the Total Environment, 268, 197, 2001.

9. PAHLEVAN N., ZHONGPING LEE, JIANWEI WEI, SCHAAF C.B., SCHOTT J.R., BERK A. On-orbit radiometric characterization of OLI (Landsat-8) for applications in aquatic remote sensing. Remote Sensing of Environment 154, 272, 2014.

10. MOBLEY C.D. Light and water: radiative transfer in natural waters. San Diego: Academic, 592, 1994.

11. PALANDRO D.A., ANDRÉFOUËT S., HU C., HALLOCK P., MÜLLER-KARGER F.E., DUSTAN P., et al. Quantification of two decades of shallow-water coral reef habitat decline in the Florida Keys National Marine Sanctuary using Landsat data (1984-2002). Remote Sensing of Environment, 112, 3388, 2008.

12. KONDRATYEV K.Y., FILATOV N.N. Limnology and remote sensing. Springer-Praxis Series in Remote Sensing. Praxis Publishing Ltd. Chichester, UK, 406, 1999.

13. DE LOS RÍOS-ESCALANTE P., ACEVEDO P. First observations on zooplankton and optical properties in a glacial north Patagonian lake (Tagua Tagua lake, $41^{\circ} \mathrm{S}$ 
Chile). Polish Journal of Environmental Studies, 25, 453, 2016.

14. DE LOS RIOS-ESCALANTE, P., ACEVEDO, P.,. First observations of Boeckella michaelseni Mrázek 1901 and optical properties of a Central Patagonian lake. Polish Journal of Environmental Studies 25, 1781, 2016.

15. DE LOS RÍOS-ESCALANTE P., QUINAN E., ACEVEDO P. Crustacean zooplankton communities in lake General Carrera $\left(46^{\circ} \mathrm{S}\right)$ and their possible association with optical properties. Crustaceana, 86, 507, 2013.

16. MODENUTTI B.E., BALSEIRO E.G., QUEIMALIÑOS C.P., SUAREZ D.A., DIÉGUEZ M.C. ALBARIÑO R.J. Structure and dynamics of food webs in Andean lakes. Lak. Reserv., Res. Manage., 3, 179, 1998.

17. SOTO D. Oligotrophic patters in southern Chilean lakes: the relevance of nutrients and mixing depth. Rev. Chil. Hist. Nat., 75, 377, 2002.

18. KROGH S.A., POMEROY J.W., McPHEE J., Physically based mountain hydrological modeling using reanalysis data in Patagonia. Journal of Hydrometeorology, 16, 172, 2015.

19. PASQUINI A.I., DEPETRIS P.J., Southern Patagonia's Perito Moreno Glacier, Lake Argentino and Santa Cruz river hydrological system: an overview. Journal of Hydrology, 405, 48, 2011.

20. LASPOUMADERES C., MODENUTTI B., SOUZA M., BASTIDAS M., CUASSOLO F., BALSEIRO E., Glacier melting and stoichiometric implications for lake community structure: zooplankton species distributions across a natural light gradient. Global Change Biology, 19, 316, 2013.

21. HYLANDER S., JEPHSON T., LEBRET, K., VON EINEM J., FAGEBERG T., BALSEIRO E., MODENUTTI B., SOUZA M., LASPOUMADERES, C., JÖHNSON M., LJUNGBERG P., NICOLLE A., NILSSON P.A., RANAKER L., HANSSON L.A. Climate-induced input of turbid glacial meltwater affects vertical distribution and community composition of phyto- and zooplankton. Journal of Plankton Research, 33, 8, 1239, 2011.

22. PALMER S.C.J., HUNTER P.D., LANKESTER T., HUBBARD S., SPYRAKOS E., TYLER A.N., PRÉSIG M., HORVATH H., LAMB, A., BALSTER H., TOTH V.R., Validation of envisat MERIS algorithms for chlorophyll retrieve in a large turbid and optically-complex shallow lake. Remote Sensing of Environment, 157, 158, 2015.

23. DE LOS RIOS-ESCALANTE, P., ACEVEDO, P., PANDOURSKI, I. Spectral properties observations: a first comparison of Bulgarian and Chilean mountain lakes. Polish Journal of Environmental Studies 25, 2701, 2016.

24. PALMER S.C.J., KUTZER T., HUNTER P.D. Remote sensing of inland waters: challenges, progress and future directions. Remote sensing of Environment, 157, 1, 2015. 